\title{
DYNAMIC EFFECTS OF U.S. BUDGET DEFICIT AND LABOR PRODUCTIVITY-REAL WAGE GAP ON US STOCK MARKET PERFORMANCE
}

\author{
Matiur Rahman \\ McNeese State University • Lake Charles, Louisiana \\ Muhammand \\ South Carolina State University • Orangeburg, South Carolina
}

\section{ABSTRACT}

This paper investigates the dynamic effects of annual U.S budget deficit as a ratio of GDP and labor productivity-real wage gap on US stock market performance. The sample period runs from 1950 through 2012. The standard cointegration methodology is appropriately applied. All the aforementioned variables are nonstationary in levels revealing I(1) behavior. The coefficient of the error-correction term of the vector error-correction model (VECM) has expected negative sign with statistical significance confirming long-run unidirectional causality stemming from the independent variables to the stock market return. However, the speed of adjustment towards a long-run equilibrium is slow as reflected in the low numerical coefficient of the error-correction term. The evidences on short-run interactive feedback effects are also very weak.

Keywords: Budget Deficit, Productivity-Real Wage Gap, Unit Root, Cointegration, Vector Error-Correction Model

JEL classification code: E60, G10

\section{INTRODUCTION}

U.S. Federal budget deficits have been perennial at sustainable levels throughout the US history excepting several years, occasionally. The net effect of the budget deficits on stock market returns is confounding and uncertain through interest rate and price channels depending on the methods of financing. This issue remains a puzzle inspiring numerous empirical studies. In theory, rising deficit boosts federal demand for loanable funds that, in turn, lifts interest rate and crowds out private investment. This decline in private investment reduces corporate capital stock with which to work. This contracting capital stock decreases future earnings growth and cash inflows. In addition, rising interest rate used as a discount factor depresses stock prices. Monetization of increases in budget deficits through quantitative eas- 
ing lowers interest rates and causes higher expected inflation. Both exert opposing influences on stock prices.

In finance, the valuation of stocks depends on the expectation of the current and future cash flows from equities, the risks inherent in those flows, and rate at which those flows are discounted. Stock prices are also influenced by changes in economic activity, interest rate, and inflation, among other macroeconomic fundamentals. Their net effect on stock market at some point of time is ambiguous. Efficient market hypothesis in weak-form further claims that budget deficits have little effect on future stock prices as the past deficits are already incorporated in the current stock prices. Stock price behaviors have important bearings on private sector capital formation, market liquidity, allocative efficiency and economic prosperity meriting further empirical inquiries.

The unprecedented rise in U.S. budget deficit and uncharted behavior of U.S. stock market during 2008-2010 renewed interest in studying further the relation between budget deficits and stock prices. Economic theories are unsettling to provide a clear explanation to this uneasy and complex relationship. The effects of rising budget deficits due to income tax cuts or federal spending spree or both on stock prices primarily depend on the state of the economy and the methods of financing the deficits. To explain further, (i) increase in income tax reduces disposable income to spend on consumption goods. This reduces aggregate demand. Given the aggregate supply constraint, prices of consumer goods decline resulting in depressed corporate earnings and hence lower stock prices, ii) financing by federal borrowing from loanable funds market raises interest rate that, in turn, reduces stock prices, and (iii) partial or full monetization of deficits by accommodative monetary easing lowers interest rate without risk of surging inflation, if the economy is at lessthan-full employment. This will help lift stock prices. Furthermore, if the economy is at full employment, monetary easing will raise the fear of future resurgence of inflation with dampening effects on stock market as rational investors will reshuffle their portfolios by reallocating funds from financial assets to real assets for hedging purposes. Thus, the net effect of budget deficits on stock prices at best is uncertain.

Labor productivity and real wage gap is another piece of puzzle in macroeconomics literature. The growth in real hourly compensation in the US nonfarm business sector has slowed to 0.4 percent a year from 2.4 percent a year over 1960-1973 (Bosworth and Perry, 1994). The relationship between labor productivity and nonfarm real wage is nonlinear (quadratic) with inverted U-curve (Tang, 2012). So, the net effect of this gap on stock prices is again confounding and uncertain. In common sense term, a rising gap raises corporate profit that is used partly to pay higher divi- 
dends to shareholders. This, in turn, boosts stock prices. Although labor productivity is an important determinant of wage, gains are distributed more in favor of capital than labor since workers are being paid discernibly below their marginal revenue products. The absence of a strong relationship between labor productivity and real wage is unlikely to boost consumption growth with a subdued effect on stock prices due to lackluster sales growths.

The primary objective of this study is, thus, to explore the influences of US annual budget deficit as ratio of GDP and labor productivity-real wage gap on U.S. stock market. The standard cointegration framework is invoked to investigate this intricate issue of great importance in view of their puzzling nature. In particular, the casual nexus of stock market and labor productivity-real wage gap is heavily underresearched. The rest of the paper is organized as follows. Section II provides a brief review of the related literature. Section III outlines the empirical methodology and describes data. Section IV reports empirical results. Section V offers conclusions.

\section{BRIEF REVIEW OF RELATED LITERATURE}

Tobin (1969), in his general equilibrium approach of the financial sector, highlighted the role of stock returns as the linkage between the real and the financial sectors of the economy and showed how both money growth and budget deficits can have an important impact on stock returns. In this connection, theoretical discussion/ models are also put forth by (Blanchard, 1981, and Shah, 1984). It is a well-known fact that government actions (or fiscal decisions) are likely to influence future monetary policy actions (Thorbecke, 1997; and Patelis, 1997).

Based on theory and empirical evidences, the expected directional impact of the budget deficit on stock returns should be negative. Government budget deficits exert upward pressure on the nominal interest rate or the discount rate, as applied to the firm. This, in turn, lowers expected returns as the risk premium increases (Geske and Roll, 1983). Geske and Roll also note that increases in risk premia due to federal budget deficits expose investors to an uncertainty surrounding the reaction of the Federal Reserve and thus further confound the equity market behavior.

Several studies have focused on the relationship between fiscal policy (budget deficits) and stock market behavior. These studies examined primarily stock market efficiency with respect to fiscal actions (e.g., Rogalski and Vinso, 1977; Darrat, 1988; Darrat and Brocato, 1994; and Lee, 1997). Although the theoretical motivation on the effects of fiscal policy on the stock market (or asset prices) have been laid out more than thirty years ago (e.g., Tobin, 1969; Blanchard, 1981; and Shah, 
1984), the empirical front on the issue has been lagging, both for the U.S. and other countries (Darrat, 1988; and Ali and Hasan, 2003). Perhaps, this was due to the assumption of Barro's (1974) Ricardian Equivalence Proposition (of debt-neutrality), which asserts that deficits do not matter if individuals correctly expect and discount future tax increases from current tax decreases thus leaving their net worth unaffected. Subsequent investigations, however, have produced mixed results. For instance, some studies have shown support for the proposition (e.g., Evans, 1987a, b; and Boothe and Ried, 1989), others have produced results to the contrary (Frenkel and Razin, 1986; and Zahid, 1988).

Conventional analysis suggests that sustained budget deficits have profound implications on interest rates, national saving and the external account (Gale and Orszag, 2003, 2004; Engen and Hubbard, 2005). Thus, going beyond the traditional analysis, large future deficits entail additional risks to the economy which includes a loss in domestic and foreign investor confidence and adverse effects on the exchange rate. Specifically, a loss in investor and business confidences would cause a shift of portfolios away from home-currency assets into foreign-currency assets, thereby placing a downward pressure on the domestic currency and an upward pressure on the interest rate. This would limit the ability of the country to finance its liabilities and increase the country's exposure to exchange rate fluctuations.

In contrast, higher government deficits may also encourage higher money growth, resulting from an accommodative behavior of the Federal Reserve or a decline in interest rates. Empirical evidences on this behavior have offered mixed results. Specifically, Allen and Smith (1983) and Barnhart and Darrat (1989) report a negative relationship between federal budget deficits and money growth. Furthermore, DeLeeuw and Holloway (1985) and Hoelscher (1986) provide evidence of a positive linkage between the above. Therefore, this is still an issue of further empirical investigation.

Additionally, the effects of money growth on stock returns can be approached from two theoretical perspectives, namely, the efficient market approach (Cooper, 1974; and Rozeff, 1974) and the general equilibrium portfolio approach. The first approach simply argues that all past information incorporated in the money supply data is reflected in current stock returns and so money supply changes should have no impact on stock returns excepting a possible contemporaneous effect. The second perspective suggests that investors attempt to hold an equilibrium position among all assets, including money and equities. An exogenous shock that increases the money supply would temporarily disturb this equilibrium until investors substitute money for other assets. So, equities respond to monetary disturbance with a lag and that lag 
could, theoretically, be linked to an interest-rate effect, a corporate-earnings effect, a risk-premium effect and so on (Hamburger and Kochin, 1971).

The conventional wisdom about the role of stocks is that they provide a hedge against inflation or the Fisherian hypothesis of positive relationship of nominal equity returns with inflation. However, evidences provided by Fama and Schwert (1977), Geske and Roll (1983), and McCarthy et al., (1990) suggest a negative relationship between stock returns and inflation. A re-examination of the issue by James et al., (1985), Wei and Wong (1992), and Lee (1992) found support for this hypothesis, while Park (1997), Siklos and Kwok (1999) and Laopodis (2006) found evidence against it. Thus, this issue is still stirring empirical controversies and remains to be empirically resolved.

More recently, Quayes (2010) studied the association between budget deficit and stock prices by integrating the effects of inflation and demographic structure. Results from the cointegration analysis show that both budget deficit and inflation have negative impact on stock prices. Saleem, et.al. (2012) examine the long-run causal relationship between budget deficit and stock market for India and Pakistan. Results show that due to high development expenditures in Pakistan, a long-term positive relationship is observed between budget deficit and stock market. In India, a negative relationship is observed between both variables due to increase in current expenditures. In Pakistan, a causal relationship runs from budget deficit to stock market while no causal relationship exists between budget deficit and stock market in India.

Empirical studies investing the labor productivity and wage relationship are abundant. To cite a few recent ones, Mora, et al. (2005) investigated the relationship between wages and labor productivity in 11 European countries for 1981-2001 and found that the gap between nominal wages and labor costs decreased. However, they did not observe a similar decrease of the gap between real wages and labor productivity. Lopez-Villavicencio and Silva (2010) analyzed macroeconomic data of OECD countries between 1985 and 2007. They found that wage increase exceeded productivity growth of permanent workers. For temporary workers, it was just the opposite.

Narayan and Smyth (2009), using the co-integration technique, investigated the relationship among inflation, real wages and growth of labor productivity in the G-7 Countries for 1960-2004. They found a positive relationship between real wages and productivity growth. Verbic and Kuzmin (2009) explored the relationship between wages and labor productivity in Slovenia over 1998-2007. They confirmed the hypothesis of high dependence of wages on labor productivity. Sidhu (2010) 
found that labor productivity had a strong influence on determining wages in the Indian economy. One percent increase of labor productivity led to about 0.39 percent increase of wage rates in India. Tang (2012) empirically investigated the impact of real wages on labor productivity in the Malaysian manufacturing sector using annual data for 1980-2009. This study found a quadratic relationship (i.e. inverted U-shaped curve) between labor productivity and real wage instead of a linear relationship.

To our knowledge, the empirical literature on this issue is very scant. A widening labor productivity-wage gap contributes to surges in stock prices. Rising productivity boosts aggregate supply (AS). But real wage gains lag behind labor productivity gain. As a result, profits rise sharply causing an upsurge in the demand for company shares raising their prices (Batra, 1999 and 2003). Using quarterly US data for the period of 1970-2000, Rashed and Samanta (2005) demonstrated a strong positive relationship between labor productivity — wage gap and the stock price within a macroeconomic framework, as suggested in Batra (1999).

\section{EMPIRICAL METHODOLOGY AND DATA}

The estimating base equation is specified as follows:

$$
\mathrm{SPR}_{\mathrm{t}}=\alpha+\beta_{1} \mathrm{BDG}_{\mathrm{t}}+\beta_{2} \mathrm{PRC}_{\mathrm{t}}+\mathrm{e}_{\mathrm{t}}
$$

where, $\mathrm{SPR}=\mathrm{US} \mathrm{S \& P} 500$ return, $\mathrm{BDG}_{\mathrm{t}}=$ Annual US real budget deficit as ratio of real GDP, and PCR = labor productivity-real wage gap (productivity/real wage). The causal effect of each explanatory variable on S\&P 500 is unidirectional, not bidirectional. So, reverse specifications of equation (1) are not necessary. Prior to testing for cointegration, the time series properties of the variables involved are examined. To test for unit root (nonstationarity) in the variables, the efficient modified Dickey-Fuller test (DF-GLS), the efficient modified Phillips-Perron test (Elliot et al. 1996; Ng and Perron 2001) and their counterpart KPSS (Kwiatkowski, Phillips, Schmidt and Shin 1992) test for no unit root (stationarity) are implemented instead of the standard ADF and PP tests for their high sensitivity to the selection of lag-lengths. It is important to examine the time series properties of variables since an application of the Ordinary Least Squares (OLS) to estimate a model with nonstationary time series data results in the phenomenon of spurious regression (Granger and Newbold, 1974) invaliditating the inferences through the standard t-test and joint F-test (Phillips, 1986). To be cointegrated, variables must possess the same order of integration, i.e., each variable must become stationary on first-order differencing of level data depicting I(1) behavior. 
Second, the cointegration procedure, as developed in Johansen $(1988,1992$, 1995) and Johansen and Juselius (1990), is implemented that allows interactions in the determination of the relevant macroeconomic variables and being independent of the choice of the endogenous variables. It also allows explicit hypothesis testing of parameter estimates and rank restrictions using likelihood ratio tests. The empirical exposition of the Johansen-Juselius methodology is as follows:

$$
\Delta \mathrm{V}_{\mathrm{t}}=\tau+\Omega \mathrm{V}_{\mathrm{t}-1}+\sum_{\mathrm{j}=1}^{\mathrm{k}-1} \Omega_{\mathrm{j}} \mathrm{V}_{\mathrm{t}-\mathrm{j}}+\mathrm{m}_{\mathrm{t}}
$$

where, $V_{t}$ denotes a vector of SPR, BDG and PRC, and $\Omega=\alpha \beta^{\prime}$. Here, $\alpha$ is the speed of adjustment matrix and $\beta$ is the cointegration matrix. Equation (2) is subject to the condition that $\Omega$ is less-than-full rank matrix, i.e., $r<\mathrm{n}$. This procedure applies the maximum eigenvalue test $\left(\lambda_{\max }\right)$ and trace test $\left(\lambda_{\text {trace }}\right)$ for null hypotheses on r. Both tests have their trade-offs. $\lambda \max$ test is expected to offer a more reliable inference as compared to $\lambda_{\text {trace }}$ test (Johansen and Juselius (1990), while $\lambda_{\text {trace }}$ test is preferable to $\lambda_{\max }$ test for higher testing power (Lütkepohl, et al., 2001)). However, the JohansenJuselius test procedure is also not immune to supersensitivity to the selection of laglengths. The optimum lag-lengths are determined by the AIC (Akaike Information Criterion), as developed in Akaike (1969).

Third, on the evidence of cointegrating relationship among the variables, there will exist an error-correction representation (Engle and Granger, 1987). The vector error-correction model takes the following form:

$$
\Delta \mathrm{SPR}_{\mathrm{t}}=\beta_{1} \mathrm{e}_{\mathrm{t}-1}+\sum_{\mathrm{i}=1}^{\mathrm{k}} \phi_{\mathrm{i}} \Delta \mathrm{SPR}_{\mathrm{t}-\mathrm{i}}+\sum_{\mathrm{j}=1}^{\mathrm{k}} \delta_{\mathrm{j}} \Delta \mathrm{BDG}_{\mathrm{t}-\mathrm{j}}+\sum_{\mathrm{j}=1}^{\mathrm{k}} \psi_{\mathrm{j}} \Delta \mathrm{PRC}_{\mathrm{t}-\mathrm{j}}+\mathrm{u}_{\mathrm{t}}
$$

Equation (3) corresponds to original equation (1). Here, $e_{t-1}$ is the error-correction term of equation (3). If $\beta_{1}$ is negative and statistically significant in terms of the associated t-value, there is evidence of a long-run causal flow to the dependent variable from the relevant explanatory variables. If $\delta_{j}$ 's, $\phi_{i}$ 's, and $\psi_{j}$ 's do not add up to zero, there are short-run interactive feedback relationships in equation (3).

Annual data from 1950 through 2012 are employed. The time-span over 60 years is quite sufficient for meaningful cointegration analyses (Hakkio and Rush, 1991). Data sources include New York Stock Exchange for S\&P 500(SPR), U.S. Department of Commerce for nominal budget deficits (BDG) and real GDP; and Bureau of Labor Statistics for labor productivity and hourly real wage. Nominal budget deficits are deflated by consumer price indices of corresponding years. Annual data 
are used for all variables due to availability of budget deficits data only on yearly basis, although quarterly data are available for other variables.

\section{EMPIRICAL RESULTS}

First, to describe the nature of data distribution of each variable, the standard statistical descriptors are computed. They are reported as follows:

Table 1

Descriptive Statistics

Sample: (1950 - 2011)

\begin{tabular}{|c|c|c|c|c|c|c|}
\hline SERIES & MEAN & MEDIAN & STDEV & SKEWNESS & KURTOSIS & $\begin{array}{c}\text { JARAQUE- } \\
\text { BERA }\end{array}$ \\
\hline SPR & 5.2458 & 4.7809 & 1.261 & 0.19338 & 1.8302 & 23.9212 \\
\hline BDG & -15.0106 & -14.4790 & 23.8862 & -2.3498 & 9.5430 & 167.6576 \\
\hline PRC & 0.8630 & 0.8374 & 0.10453 & 0.34089 & 1.7000 & 55.56644 \\
\hline
\end{tabular}

The above standard descriptors confirm near-normality in the data distribution of each time series variable in terms of mean-to-median ratio being close to unity and moderate skewness. The Jarque-Bera statistics also reaffirm the above inference.

Second, pairwise simple correlation coefficients of the variables are reported as follows:

Table 2

\section{Correlation Matrix}

\begin{tabular}{|c|c|c|c|}
\hline SERIES & SPR & BDG & PRC \\
\hline SPR & 1.000000 & 0.138875 & 0.63384 \\
\hline BDG & -0.44603 & 1.000000 & -0.42927 \\
\hline PRC & 0.633842 & -0.429275 & 1.000000 \\
\hline
\end{tabular}

As evidenced in Table 2, each correlation coefficient has expected sign. The coefficients range from -0.44603 to 0.63384 , as observed above.

Third, time series property of nonstationarity/stationarity in each variable is examined by the applications of DF-GLS, Ng-Perron and KPSS tests. Their calculated values are reported as follows: 
Table 3:

Unit Root Tests*

\begin{tabular}{|c|c|c|c|c|c|c|}
\hline \multirow{2}{*}{ SERIES } & \multicolumn{3}{|c|}{ LEVEL } & \multicolumn{3}{c|}{ First DIFFERENCES } \\
\cline { 2 - 7 } & DF-GLS & NG-PERRON & KPSS & DF-GLS & NG-PERRON & KPSS \\
\hline SPR & -1.1263 & -1.4132 & 0.957 & -6.5366 & -26.677 & 0.1148 \\
\hline BDG & -0.50929 & -1.9411 & 0.5735 & 6.402502 & -28.4310 & 0.24003 \\
\hline PRC & -1.70283 & -5.444 & 0.6201 & -8.62633 & -29.568 & 0.08928 \\
\hline
\end{tabular}

*The modified Dickley-Fuller (DF_GLS) critical values are -2.653 and

-1.954 at $1 \%$ and $5 \%$ levels of significance, respectively.

The Modified Phillips-Perron (Ng-Perron) critical values are -13.00

and -8.10 at $1 \%$ and $5 \%$ levels of significance, respectively.

The KPSS critical values are 0.7 and 0.347 at $1 \%$ and $5 \%$ levels of significance, respectively.

As depicted in Table 3, DF-GLS, Ng-Perron and KPSS tests reveal nonstationarity of each variable by rejecting the associated null hypothesis at $1 \%$ and $5 \%$ levels of significance. Each variable also displays I(1) behavior since first-differencing of level data restores stationarity, as shown above.

Fourth, as all the variables are nonstationary in levels and depict I(1) behavior. As a result, $\lambda_{\text {trace }}$ and $\lambda_{\text {max }}$ tests are applied to explore the possibility of cointegration. Their computed values are reported as follows:

Table 4

Johansen Multivariate Cointegration Test Results

Series: SPR, BDG, PRC

\begin{tabular}{|c|c|c|c|c|}
\hline $\begin{array}{c}\text { Hypothesized } \\
\text { No. of CE(s) }\end{array}$ & Eigenvalue & $\begin{array}{c}\text { Trace }\left(\boldsymbol{\lambda}_{\text {trace }}\right) \\
\text { Statistic }\end{array}$ & $\begin{array}{c}\mathbf{0 . 0 5} \\
\text { Critical Value }\end{array}$ & Prob.** \\
\hline None $^{*}$ & 0.452968 & 49.64508 & 29.79707 & 0.0001 \\
\hline At most $1^{*}$ & 0.241613 & 17.67290 & 15.4947 & 0.0231 \\
\hline At most 2 & 0.05530 & 3.015119 & 3.841466 & 0.0825 \\
\hline
\end{tabular}

Trace test indicates 1 cointegratedeqn at 0.05 level.

*denotes rejection of the null hypothesis at the 0.05 level.

**MacKinnon-Haug-Michelis (1999) p-values 


\begin{tabular}{|c|c|c|c|c|}
\hline $\begin{array}{c}\text { Hypothesized } \\
\text { No. of CE(s) }\end{array}$ & Eigenvalue & $\begin{array}{c}\text { Maximum } \\
\text { Value }\left(\boldsymbol{\lambda}_{\max }\right) \\
\text { Eigen }\end{array}$ & $\begin{array}{c}\mathbf{0 . 0 5} \\
\text { Critical Value }\end{array}$ & Prob.** \\
\hline None $^{*}$ & 0.452968 & 31.97218 & 21.13162 & 0.0010 \\
\hline At most $1^{*}$ & 0.241613 & 14.65778 & 14.26460 & 0.0433 \\
\hline At most 2 & 0.055301 & 3.015119 & 3.8414 & 0.0825 \\
\hline
\end{tabular}

Max-Eigen value test indicates 1 cointegratedegn(s) at the level 0.05 level *denotes rejection of the null hypothesis at the 0.05 level **MacKinnon-Haug-Michelis (1999) p-values

The computed values of $\lambda_{\text {trace }}$ and $\lambda_{\text {max }}$ statistics being higher than their respective critical values at 5\% level of significance clearly reject the null hypothesis of no cointegration. In other words, there exists converging relationship among the variables towards a long-run equilibrium. This is due to one cointegrating vector that drives the dynamic system to converge towards a long-run equilibrium.

Finally, on the evidence of cointegrating relationship among the variables, vector error-correction model (3) is estimated for long-run causal flows with convergence and short-run dynamic interactive feedback relationship among the variables. The estimates are reported in equation (3)', as follows:

$$
\begin{aligned}
& \Delta \mathrm{SPR}_{\mathrm{t}}=\underset{(-2.3005)^{-0.1}}{-0.0373} \hat{\mathrm{e}}_{\mathrm{t}-1}+\underset{(1.1059)}{0.1658 \Delta \mathrm{SPR}_{\mathrm{t}-1}}-\underset{(-1.2726)}{-0.2105 \Delta \mathrm{SPR}_{\mathrm{t}-2}}+\underset{(1.0018)}{0.0018 \Delta \mathrm{BDG}_{\mathrm{t}-1}} \\
& +\underset{(0.8870)}{0.0086 \Delta \mathrm{BDG}_{\mathrm{t}-2}-0.0115 \Delta \mathrm{pcp}_{\mathrm{t}-1}-0.2634 \Delta \mathrm{PCP}_{\mathrm{t}-2}} \\
& \overline{\mathrm{R}}^{2}=0.0336, \mathrm{~F}=1.2877, \mathrm{AIC}=-1.1310
\end{aligned}
$$

As observed in equation (3)', there exists a long-run unidirectional causal flow from the lagged independent variables to the current change in S\&P500 (SPR). This inference is based on the expected negative sign of the coefficient of the error-correction term $\left(\hat{e}_{t-1}\right)$ and its statistical significance in terms of the associated $t$-value. But its numerical coefficient (-0.0373) indicates very slow speed of adjustment towards a long-run equilibrium. There are weak evidences of short-run interactive feedback effects within the system in terms of the statistical insignificance as reflected in the associated individual t-values. $\overline{\mathrm{R}}^{2}$ reveals that merely $3.36 \%$ of $\Delta \mathrm{SPR}_{\mathrm{t}}$ is explained by the independent variables. The F-statistic at 1.2877 shows statistical insignificance of the overall equation (3)'. This is also charted graphically in the Appendix. These findings are consistent with those of a host of empirical studies, as cited in the literature review section of this paper. 


\section{CONCLUSIONS}

To summarize, time series data on stock market return, Federal annual real budget deficit as ratio of corresponding annual real GDP and labor productivity-real wage gap are nonstationary in levels and reveal I(1) behavior. All three variables are found cointegrated in terms of both $\lambda_{\text {trace }}$ and $\lambda_{\max }$ tests. The estimates of the VECM confirm long-run unidirectional causal flows from the lagged independent variables to the contemporaneous stock market return with slow speed of adjustment towards a long-run equilibrium. The evidences show very weak short-run interactive feedback effects among the variables.

In closing, real budget deficit and labor productivity- real wage gap have long-run implications for US stock market performance with no significant short-run influences. Thus, theoretical analyses partly meet empirics in the long run, though not in the short run.

\section{REFERENCES}

Akaike, H., (1969). Fitting autoregressive for prediction. Journal Annals of the Institute of Statistical Mathematics, 21(1), 243-247.

Allen, S. D., \& Smith, M.D. (1983), Government borrowing and monetary accommodation. Journal of Monetary Economics 12(4), 605-616.

Ali, S.M., \& Hasan, M.A., (1993). Is the Canadian stock market efficient with respect to fiscal policy? Some vector autoregression results. Journal of Economics and Business 45(1), 45-59.

Barnhart, S.W., \& Darrat, A.F. (1989). Federal deficits and money growth in the United States: A vector autoregressive analysis. Journal of Banking and Finance 13(1), 137-149.

Barro, R.J. (1974). Are government bonds net wealth? Journal of Political Economy 82(6), 1095-1117.

Batra, R. N. (1999). The crash of the millennium: Surviving the inflationary depression, New York: Harmony Books, 1999.

Batra, R., (2003). Common sense macroeconomics, Richardson: Liberty Press, 2003. Blanchard, O. J. (1981). Output, the stock market and interest rates. American Economic review 71(1), 132-143.

Boothe, P.M., \& Reid, B.G. (1989). Asset returns and government deficits in a small open economy: Empirical evidence from Canada. Journal of Monetary Economics 23(1), 65-77. 
Bosworth, B., \& Perry G. L. (1994). Productivity and real wages: Is there a puzzle?. Brookings Papers on Economic Activity, (1), 317-344.

Cooper, R. L. (1974). Efficient capital markets and the quantity theory of money. Journal of Finance 29(3), 887-908.

Darrat, A.F. (1988). On fiscal policy and the stock market. Journal of Money, Credit and Banking 20(3), 353-363.

Darrat, A.F., \& Brocato, J. (1994). Stock market efficiency and the federal budget deficit: Another anomaly? Financial Review 29(1), 49-75.

DeLeeuw, F., \& Holloway, T.M. (1985). The measurement and significance of the cyclically-adjusted federal budget and debt. Journal of Money, Credit and banking 17(2), 232-242.

Elliot, G., Rothenberg, T.J. \& Stock, J.H. (1996). Efficient test for an autoregressive unit root. Econometrica 64(4), 813-836.

Engle, R.F. \& Granger, C.J. (1987). Co-Integration and error correction: Representation, estimation and testing. Econometrica, 55(2), 251-276.

Engen, E., \& Hubbard, R.G. (2004). Federal government debt and interest rates. National Bureau of Economic Research Macroeconomics Annual, 83.

Evans, P. (1987). Interest rates and expected future budget deficits in the United States. Journal of Political Economy, 95(1), 34-58.

Evans, P. (1987). Do budget deficits raise nominal interest rate?. Evidence from six countries. Journal of Monetary Economics, 95, 281-300.

Fama, E.F., \& Schwert, G.W., (1977). Asset returns and inflation. Journal of Financial Economics, 1977, 5(2), 115-146.

Frenkel, J.A., \& Razin, A. (1986). The international transmission and effects of fiscal policies. American Economic Review, 76(2), 330-335.

Gale, William G., \& Orszag, P. R. (2003). The economic effects of long-term fiscal discipline. Urban-Brookings Tax Policy Center Discussion Paper, No.8, April.

Gale, William G., \& Orszag, P. R. (2004). Budget deficits, national saving, and interest rates. Brookings Papers on Economic Activity, No. 2, 101-187.

Geske, R., \& Roll, R. (1983). The fiscal and monetary linkage between stock returns and inflation. Journal of Finance 38(1), 1-33.

Granger, C.W.J., \& Newbold, P. (1974). Spurious regressions in econometrics. Journal of Econometrics 2, 111-120.

Hakkio, Craig S., \& Rush, M. (1991). Co-Integration: How short is the long run?. Journal of International Money and Finance 10, 571-581.

Hamburger, M. J., \& Kochin, L. A. (1972). Money and stock prices: The channels of influence. Journal of Finance 27(2), 231-249. 
Hoelscher, G.P. (1986). New evidence on deficits and interest rates. Journal of Money, Credit \& Banking 18(1), 1-17.

James, C., Koreisha, S., \& Megan, P. (1985). A VARMA analysis of the causal relations among stock returns, real output, and nominal interest rates. Journal of Finance 40(5), 1375-1384.

Johansen, S. (1988). Statistical analysis of Co-Integration vectors. Journal of Economic Dynamics and Control 12, 231-254.

Johansen, S. (1992). Testing structural hypothesis in multivariate Co-Integration analysis of the PPP and the VIP for U.K. Journal of Econometrics, 53, 211-244.

Johansen S. (1995). Likelihood-based inference in Co-Integrated vector autoregressive models. Oxford: Oxford University Press, 1995.

Johansen, S., \& Juselius, K. (1990). Maximum likelihood estimation and inference on cointegration with applications to the demand for money. Oxford Bulletin of Economics \& Statistics 52(2), 169-210.

Kwiatkowski, D., Phillips, P.C.B., Schmidt, P. \& Shin, Y. (1992). Testing the null hypothesis of stationarity against the alternative of a unit root. Journal of Econometrics 54, 159-178.

Laopodis, N. T. (2006). Dynamic linkages among the stock market, inflation, monetary policy and real activity. Financial Review 41(4), 513-545.

Bong-Soo, L. (1992). Causal relations among stock returns, interest rates, inflation, and real activity. Journal of Finance 42(4), 1591-1603.

Lee, U. (1997). Stock market and macroeconomic policies: New evidence from Pacific Basin Countries. Multinational Finance Journal 1(4), 273-289.

Lopez-Villavicencio, A., \& Silva, J. (2010). Employment protection and the non-linear relationship between the wage-productivity gap and unemployment, working paper CEPN-CNRS: University of Paris Nord.

Lütkepohl, H., Saikkonen, P. \& Trenkler, C. (2001). Maximum eigen value versus trace tests for the cointegrating rank of a VAR process. Econometrics Journal, 4, 287-310.

McCarthy, J., Najand, M., \& Seifert, B., (1990). Empirical tests of the proxy hypothesis. Financial Review, 25, 251-264.

Mora, T., Lopez-Tamayo, J., \& Surinach, J. (2005). Are wages and productivity converging simultaneously in euro-area countries?. Applied Economics, 37(17), 2001-2008.

Narayan, P., \& Smyth, R. (2009). The effect of inflation and real wages on productivity: New evidence from a panel of G-7 countries. Applied Economics, 41(10), 1285-1291. 
Ng, S., \& Perron, P. (2001). Lag length selection and the construction of unit root tests with good size and power. Econometrica (6), 1519.

Park, S. (1997). Rationality of negative stock-price responses to strong economic activity. Financial Analysts Journal 53(5), 52-56.

Patelis, A.D. (1997). Stock return predictability and the role of monetary policy. Journal of Finance 52(5), 1951-1972.

Phillips, P.B., (1986). Understanding spurious regressions in econometrics. Journal of Econometrics, 33, 311-340.

Quayes, S. (2010). Does budget deficit lower equity prices in USA?, Economic Letters, $107(2), 155-157$.

Rashed, J.A., \& Samanta, S.K. (2005). The productivity-wage gap and the recent stock price increase: an analysis. International Review of Economics and Finance 14, 169-180.

Rogalski, R., \& Vinso, J. (1977). Stock returns, money supply and the direction of causality. Journal of Finance 32(4), 1017-1-30.

Rozeff, M.S. (1974). Money and stock prices. Journal of Financial Economics, 1, 243-302.

Saleem, F., Yasir, M., Shehzad, F., Ahmed, K., \& Sehrish, S. (2012). Budget deficit and stock prices: Evidence from Pakistan and India. Interdisciplinary Journal of Contemporary Research in Business, 4(5), 176-185.

Sidhu, H. (2010). Productivity led wage disparity in the Indian industry. Indian Journal of Industrial Relations, 45(3), 350-366.

Tang, C. F. (2012). The non-monotonic effect of real wages on labor productivity: New evidence from the manufacturing sector in Malaysia. International Journal of Social Economics, 39 (6), 391-399.

Verbic, M., \& Kuzmin, F. (2009). Coefficient of structural concordance and an example of its application: Labor productivity and wages in Slovenia. Panoeconomicus, 56(2), 227-240. 


\section{BRIEF BIOGRAPHICAL SKETCH OF AUTHORS}

Dr. Matiur Rahman is the JP Morgan Chase Endowed Professor of Finance at McNeese State University. He earned his Ph.D in Economics from Southern Methodist University. He is a very prolific researcher in macroeconomics, finance and international business. He has published very extensively in well- regarded refereed academic journals in the USA and abroad.

Dr. Muhammad Mustafa is a Professor of Economics at South Carolina State University. He is an avid researcher who has published numerous economics and finance articles in refereed US and foreign journals. His specialization is macroeconomics and applied econometrics.

\section{$\overline{\text { APPENDIX }}$}

\section{Figure 1}

$$
\begin{gathered}
\text { BDG = Budget deficit/Real GDP; PCP }=\text { Compensation/Productivity; } \\
\text { SP5 }=\log \text { of SP } 500
\end{gathered}
$$

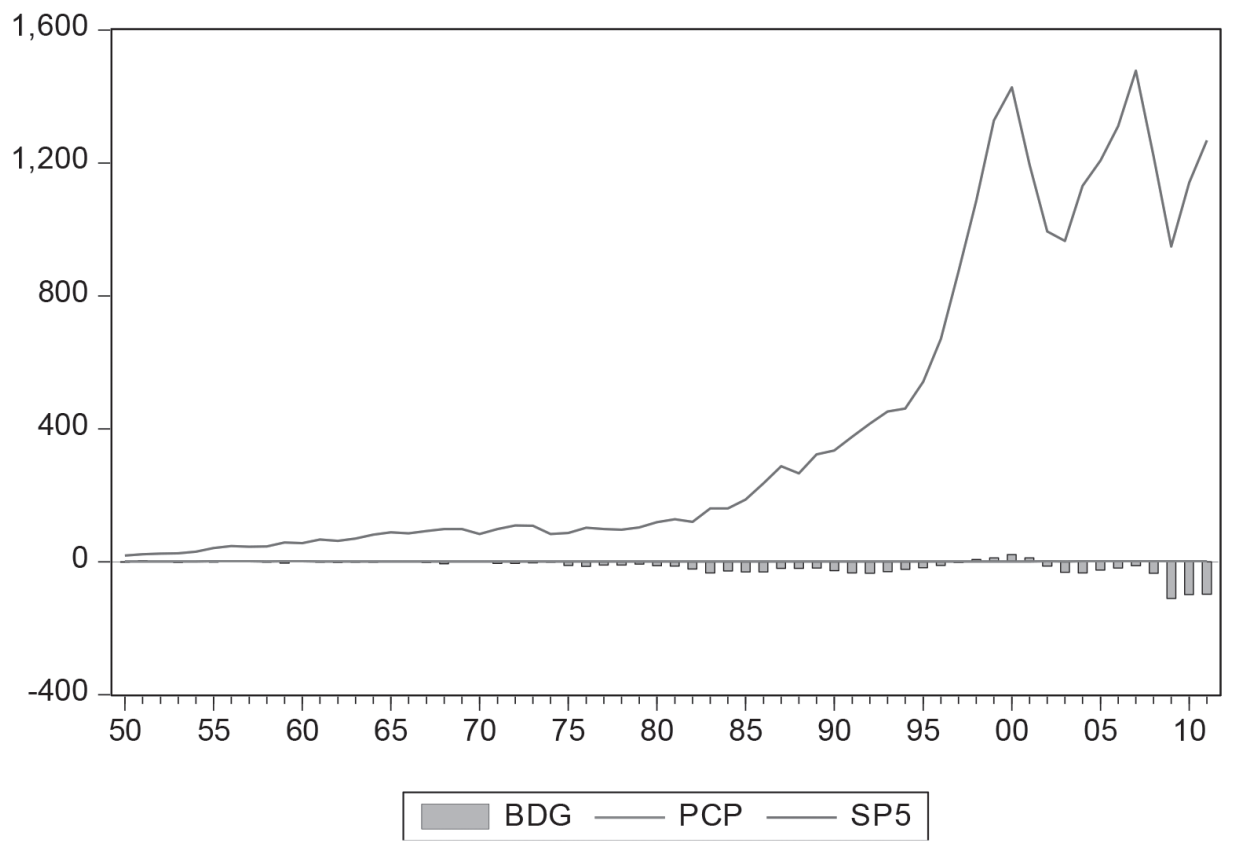

